\title{
Dental treatment in child with congenital heart disease under general anesthesia:
}

\section{Clinical case report}

\author{
Tratamento odontológico em criança com cardiopatia congênita sob anestesia geral: Relato de caso \\ clínico
}

Tratamiento dental del niño con enfermedad cardíaca congénita bajo anestesia general: Reporte de caso clínico

\begin{abstract}
Congenital heart diseases consist of structural defects of the heart and represent serious malformations, which manifest in newborns, contributing significantly to perinatal mortality. The dental management of patients with this condition may require caution by professionals, owing to the possibility of bleeding and the risk of causing an infectious endocarditis due to the variety of microorganisms residing in the oral cavity. The present case report aimed to detail dental care under general anesthesia in a hospital for a child with congenital heart disease. Female patient, 4 years old, was diagnosed with atrial and interventricular communication and hemodynamic repercussion 21 days after birth. The patient received dental treatment according to the proposed plan, which included dental restorations, conservative pulp therapy and extraction of lower anterior teeth. Posteriorly, a removable partial prosthesis was made for the patient for the purpose of functional aesthetic rehabilitation. The use of general anesthesia may reduce the risk of infective endocarditis and allows the performance of several dental procedures with a single antibiotic prophylaxis, since the cardiac pediatric patient needs a correct planning of the procedures to be performed.
\end{abstract}

Keywords: Dental care for children; General anesthesia; Heart diseases.

\section{Resumo}

As cardiopatias congênitas consistem em defeitos estruturais do coração e representam malformações graves, que se manifestam nos recém-nascidos, contribuindo significativamente para a mortalidade perinatal. O manejo odontológico de pacientes nessa condição pode exigir cautela dos profissionais, devido à chance de sangramento e ao risco de causar uma endocardite infecciosa devido à variedade de microrganismos que residem na cavidade oral. O presente relato de caso teve como objetivo detalhar o atendimento odontológico sob anestesia geral em um hospital para uma 
criança com cardiopatia congênita. Paciente do sexo feminino, 4 anos, com diagnóstico de comunicação atrial e interventricular e repercussão hemodinâmica 21 dias após o nascimento. Recebeu tratamento odontológico de acordo com o plano proposto, que incluía restaurações dentárias, terapia conservadora pulpar e exodontia de dentes anteriores inferiores. Em seguida, foi confeccionada uma prótese parcial removível para o paciente com a finalidade de reabilitação estética funcional. O uso da anestesia geral pode reduzir o risco de endocardite infecciosa e possibilitar a realização de diversos procedimentos odontológicos com uma única profilaxia antibiótica, uma vez que o paciente cardíaco pediátrico necessita de um planejamento correto dos procedimentos a serem realizados.

Palavras-chave: Assistência odontológica infantil; Anestesia geral; Doenças cardíacas.

\begin{abstract}
Resumen
Las cardiopatías congénitas consisten en defectos estructurales del corazón y representan graves malformaciones, que se manifiestan en los recién nacidos, contribuyendo significativamente a la mortalidad perinatal. El manejo odontológico de pacientes en esta condición puede requerir precaución por parte de los profesionales, debido a la posibilidad de sangrado y al riesgo de causar una endocarditis infecciosa debido a la variedad de microorganismos que residen en la cavidad bucal. El presente reporte de caso tuvo como objetivo detallar la atención dental bajo anestesia general en un hospital para un niño con cardiopatía congénita. Paciente de sexo femenino, 4 años, diagnosticada de comunicación auricular e interventricular y repercusión hemodinámica a los 21 días del nacimiento. Recibió tratamiento dental de acuerdo con el plan propuesto, que incluyó restauraciones dentales, terapia pulpar conservadora y extracción de dientes anteriores inferiores. Luego, se realizó una prótesis parcial removible para el paciente con el propósito de rehabilitación estética funcional. El uso de anestesia general puede reducir el riesgo de endocarditis infecciosa y permitió la realización de varios procedimientos dentales con una única profilaxis antibiótica, ya que el paciente pediátrico cardíaco necesita una correcta planificación de los procedimientos a realizar.
\end{abstract}

Palabras clave: Atención odontológica infantil; La anestesia general; Enfermedades cardíacas.

\title{
1. Introduction
}

Congenital malformations are associated with high mortality, estimated at about $3 \%$ of newborns, due to childhood illnesses and disabilities (Behrman \& Kliggman., 2004; Sun et al., 2015). The Interatrial communication (IAC) is an opening in the wall or septum that separates the right from the left atrium, which accounts for $10-15 \%$ of all congenital heart diseases (Almeida et al., 1998). On the other hand, the interventricular communication (IVC) is characterized by the presence of an orifice between the left and right ventricles (Almeida et al., 1998). Defects located in the lamina of the oval fossa are responsible for the absolute majority of the IVCs (Almeida et al., 1998). The condition is usually associated with complex congenital heart disease and persistence of the left superior vena cava (LSVC) (Adatia \& Gittenberger-de Groot., 1995).

Childhood heart diseases are diagnosed in the prenatal period or just after birth. The signs and symptoms of IAC and IVC depend on their size, and range from difficulty gaining weight, tiredness to breathe, rapid breathing, respiratory infections, and difficulty breastfeeding as well (Behrman \& Kliggman., 2004; Behrman \& Kliggman., 2005). When the pediatrician suspects that the patient has signs and symptoms of cardiac problems, the professional refers the case to a pediatric cardiologist, who confirms the diagnosis through physical, clinical and complementary examinations, such as electrocardiogram, chest radiograph and echocardiogram (Adatia \& Gittenberger-de Groot., 1995).

These systemic conditions require special care during invasive dental procedures, since they can cause a continuity relationship between pathogenic microorganisms from the oral cavity and damage to the patient's heart problems (Cornejo et al., 2011; Kelly et al., 2018). Accordingly, the condition is called infective endocarditis (IE) and is caused by bacteria that affect the endocardium, causing inflammation in the membrane that lines the inner wall of the heart and cardiac valves (Cornejo et al., 2011).

The IE is a rare disease caused by infections that occur in previously damaged areas, congenital malformations or problems with the lining of the chamber (Cornejo et al., 2011). In some cases, IE can be caused by viruses and fungi, but mainly by bacterial infection through the penetration of bacteria. Its virulence may vary, and into the bloodstream, bacteria may attach to the heart tissue, leading to bacterial endocarditis (Cornejo et al., 2011). 
Periodontal tissues are constantly predisposed to inflammation, becoming a potential entry-point for bacteria in the blood (American Academy of Pediatric Dentistry., 2020). The prevalence of IE directly caused in this way is little known (American Academy of Pediatric Dentistry., 2020). Various dental procedures may cause bacteremia (Chart 1), and although it is usually treated quickly by the body's immune system, it is believed that the risk of bacterial endocarditis depends on the individual reaction to the disease (Cornejo et al., 2011; Aidasani et al., 2019).

Chart 1. Some examples of pediatric dental procedures which require or not antibiotic prophylaxis.

\begin{tabular}{|l|l|}
\hline Requires antibiotic prophylaxis & Does not require antibiotic prophylaxis \\
\hline Tooth extraction, dental prophylaxis and surgeries & To take dental impression \\
\hline To place or remove orthodontic bands & To apply topic fluoride \\
\hline Local anesthesia injection & Orthodontic appliance adjustment \\
\hline Periodontal procedures & To take radiographs \\
\hline Tooth replantation & To put dental prosthesis \\
\hline Any bleeding procedure & Tooth brushing \\
\hline
\end{tabular}

Source: (Cornejo et al., 2011)

According to a systematic review by Glenny et al. (2013), patients susceptible to IE should receive antibiotic prophylaxis before undergoing any invasive dental procedure, to avoid bacterial infection (Cornejo et al., 2011; Glenny et al., 2013).

Therefore, general anesthesia can be an alternative for treating patients with dental needs and congenital heart disease, since this technique allows the performance of several dental procedures with antibiotic prophylaxis in a single session. For dental procedures with a higher risk of bleeding, especially in patients with associated diseases and on drug therapy, it is recommended to attend the hospital with multidisciplinary monitoring (American Academy of Pediatric Dentistry, 2020; Coté \& Wilson., 2006). In this context, for dentists, dealing with children with heart disease in the dentist's chair is a challenge, and it is safer to serve them with medical support, under general anesthesia in a hospital. Thus, this paper aimed to report the dental treatment under general anesthesia of a female child, 4 years old, with congenital atrial and interventricular communication and hemodynamic repercussion.

\section{Case Report}

This case was conducted in compliance with the Helsink Declaration and just after the patient's parents signed an informed consent form in accordance with the procedure. Additionally, this case was previously approved by the Institutional Research Ethics Board of the José do Rosário Vellano University (CAAE: 04337718.6.0000.5143).

A 4-year-old girl presented at Pediatric Dentistry Clinic of the School of Dentistry of José do Rosário Vellano University with her parents complaining of non-success in previous dental consultations, since the dentist was afraid due to her congenital systemic disorders. During the anamnesis, the mother reported that the child did not use any continuous medication and was diagnosed with atrial and interventricular communication and hemodynamic repercussion 21 days after birth. Thus, the dentist referred the child to a cardiologist for an evaluation of this condition, and for indication or not of antibiotic prophylaxis for future invasive dental procedures. 


\section{In the dental clinic setting:}

Firstly, the dentist confirmed the cardiologist's recommendation which was the permission for performing dental procedures using local and/or general anesthesia, but in case of invasive procedures, antibiotic prophylaxis would be required before the consultation.

The extraoral examination revealed no alteration. In turn, the intraoral, panoramic and periapical radiographic examinations (Figure 1) showed biofilm and several caries lesions, including pulp involvement and residual roots (Figure 2).

The child exhibited negative behavior according to the Frankl scale (Frankl et al., 1962) during the entire consultation, showing reluctance to accept the procedures. In addition, during radiographic examinations, the child presented episodes of forced vomiting.

Figure 1. Panoramic and periapical radiographic images. Upper anterior periapical radiography (A), lower anterior periapical radiography (B), Left interproximal radiography (C), Right interproximal radiography (D), Panoramic (E).

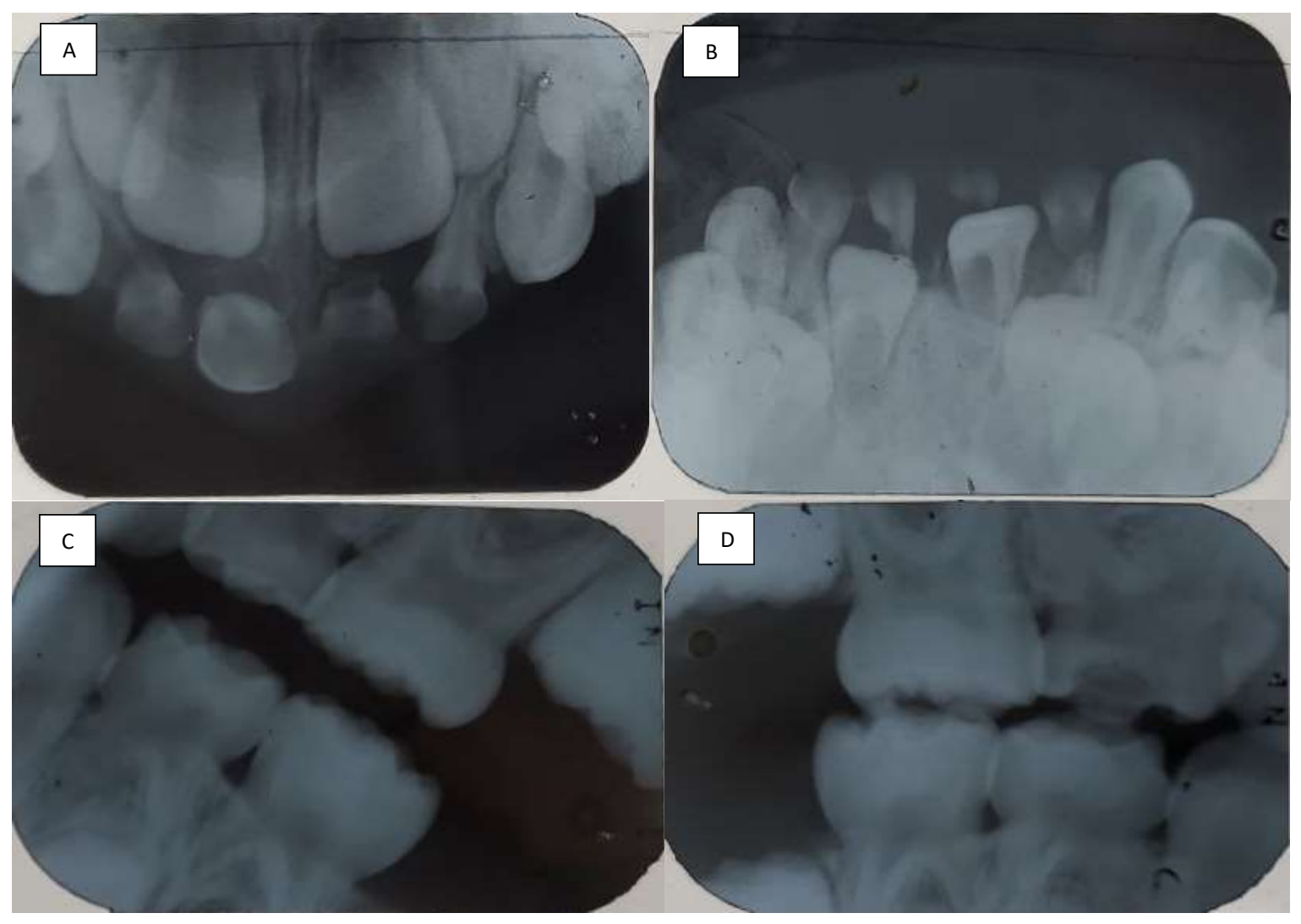


Research, Society and Development, v. 10, n. 6, e56510615907, 2021

(CC BY 4.0) | ISSN 2525-3409 | DOI: http://dx.doi.org/10.33448/rsd-v10i6.15907

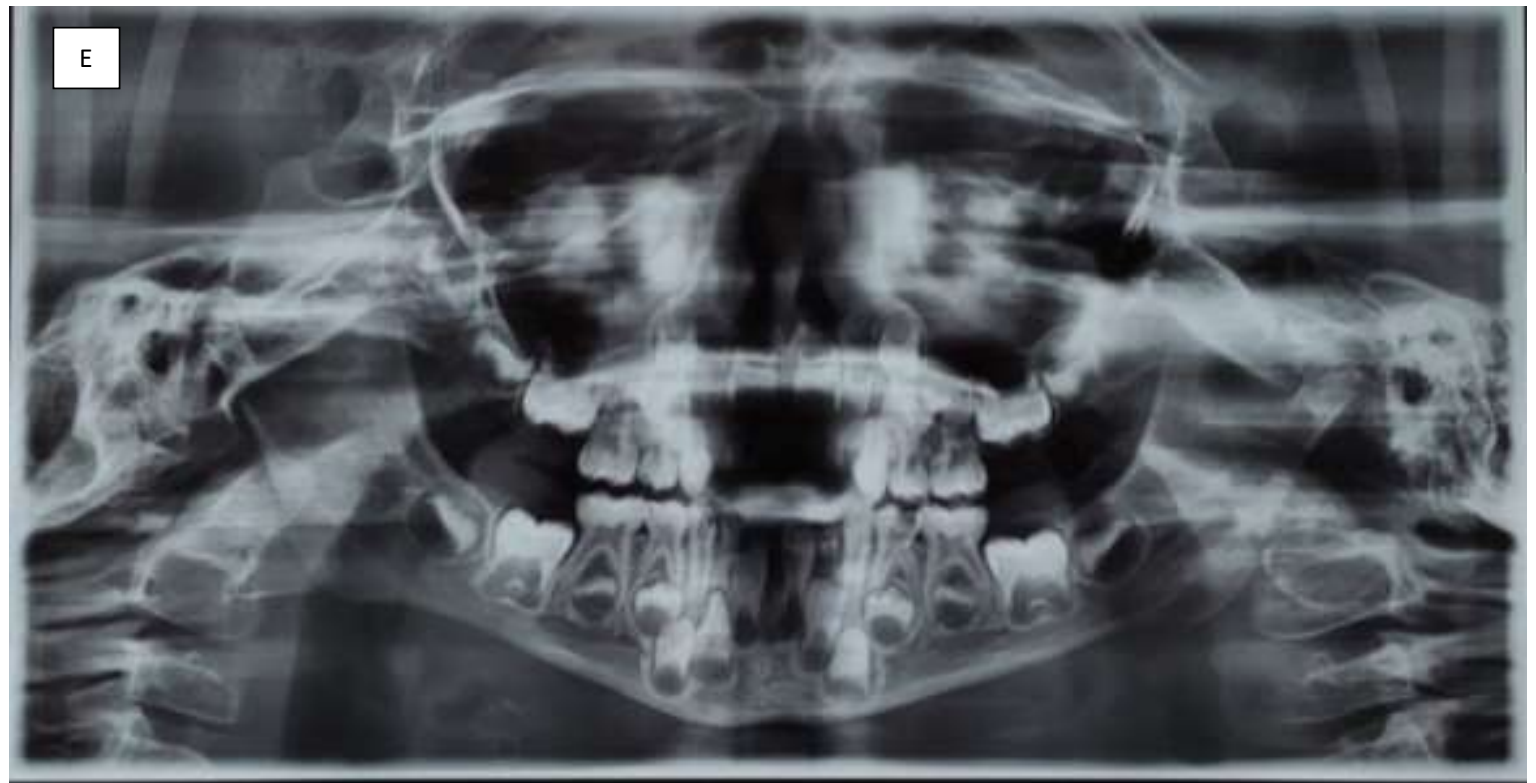

Source: Personal archive.

Figure 2. Clinical view of pretreatment of the patient's maxillary (A) and mandibular (B) arches.

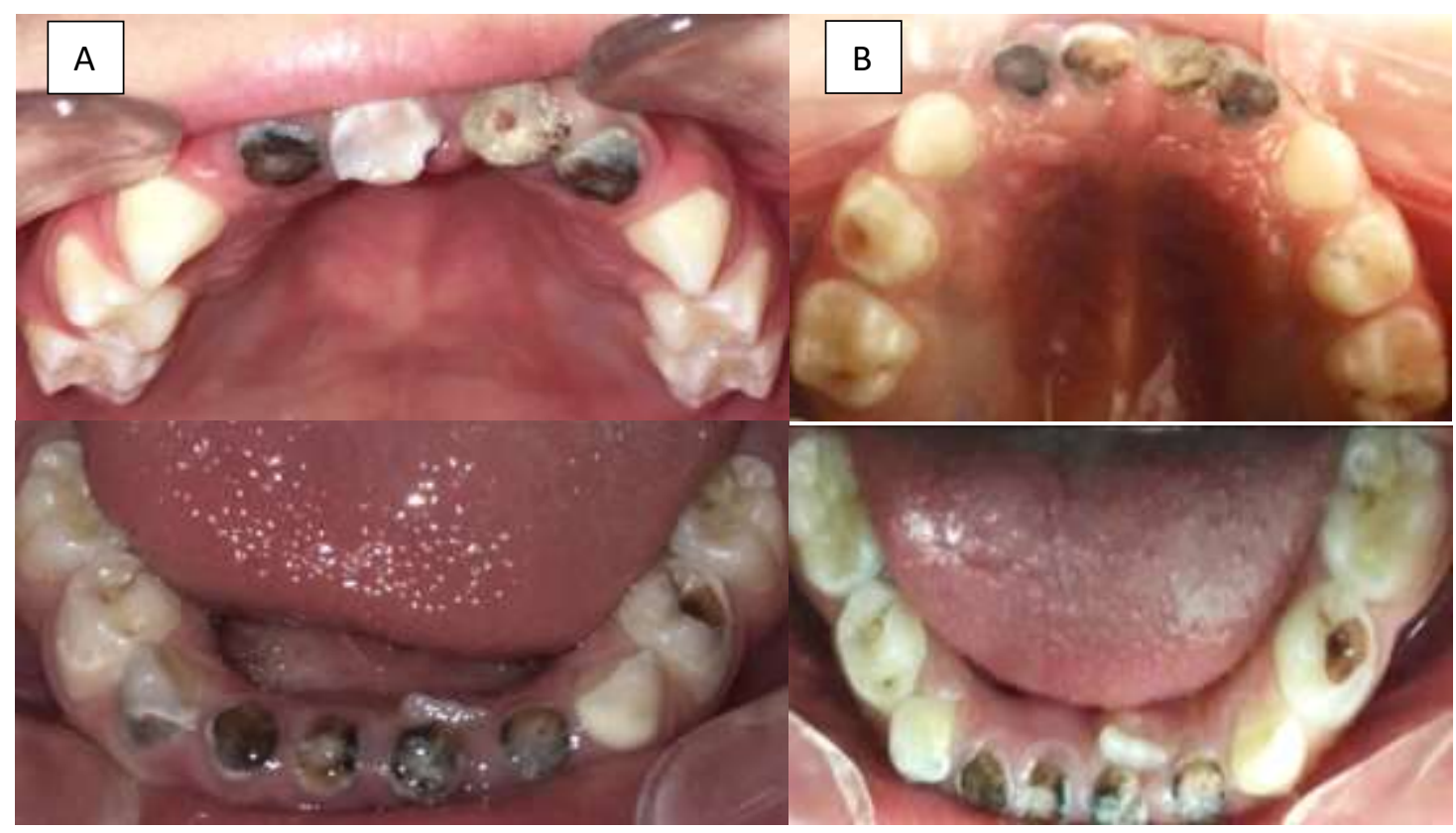

Source: Personal archive.

Due to the need for several dental attendances to perform the treatment and to the use of antibiotic prophylaxis before each one, the dental team suggested to the family to carry out the dental treatment under general anesthesia for considering the child's safety and comfort.

Thus, on the day of dental examination, all dental treatment was planned considering minimally invasive procedures. Further, dental impression of her upper and lower arches was already done for making aesthetic-functional space maintainer. 


\section{In the hospital setting}

First of all, a professional dental prophylaxis was performed using a rubber bowl with pumice at low-speed in all the teeth. Then, glass-ionomer cement (GIC) Ketac ${ }^{\mathrm{TM}}$ Molar Easymix (3M, Two Harbors, Minnesota, United States) fillings and composite sealants with Vitremer ${ }^{\mathrm{TM}}$ (3M, Two Harbors, Minnesota, United States) were done, corresponding to all invasive procedures, such as indirect pulp capping with Biocal ${ }^{\text {TM }}$ Calcium Hydroxide Lining Cement (Biodinâmica, Ibiporã, Paraná, Brazil) and tooth extractions. Finally, local fluoride varnish Duraphat ${ }^{\mathrm{TM}}$ (Colgate-Palmolive, New York City, New York, United States) was applied to all white spots. At the recovery room, after the child was asleep, functional aesthetic rehabilitation was performed with a partial removable prosthesis in the upper arch. Although there were extractions in the lower arch, it was not necessary to install aesthetic rehabilitation, because the incisors were semi erupted. All teeth corresponding to each treatment are described in Chart 2 (Figure 3). Antibiotic prophylaxis 1g of intravenous Cefazolin was performed at the time of the surgical procedure.

Figure 3. Dental team during treatment under general anesthesia in the hospital setting.

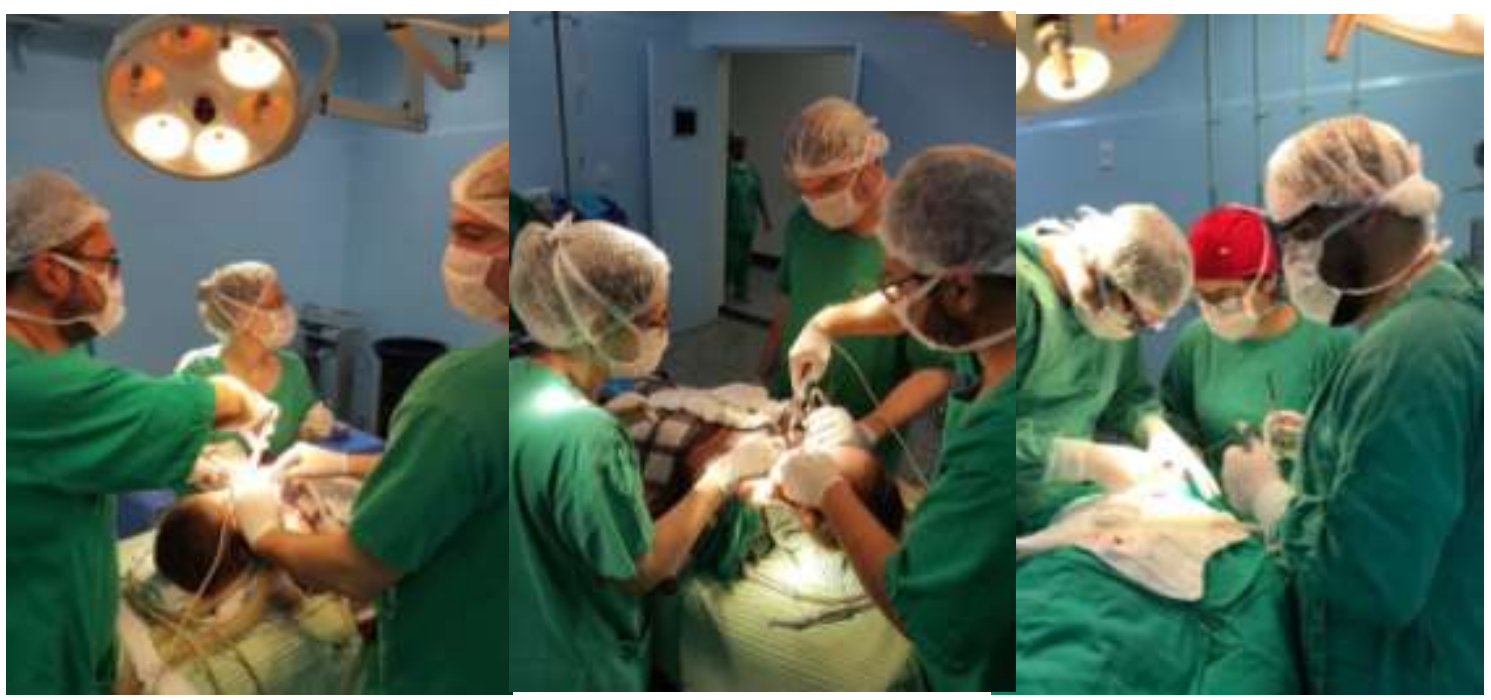

Source: Personal archive.

Figure 4. Clinical view of the patient's maxillary (A) and mandibular (B) arches after dental treatment.

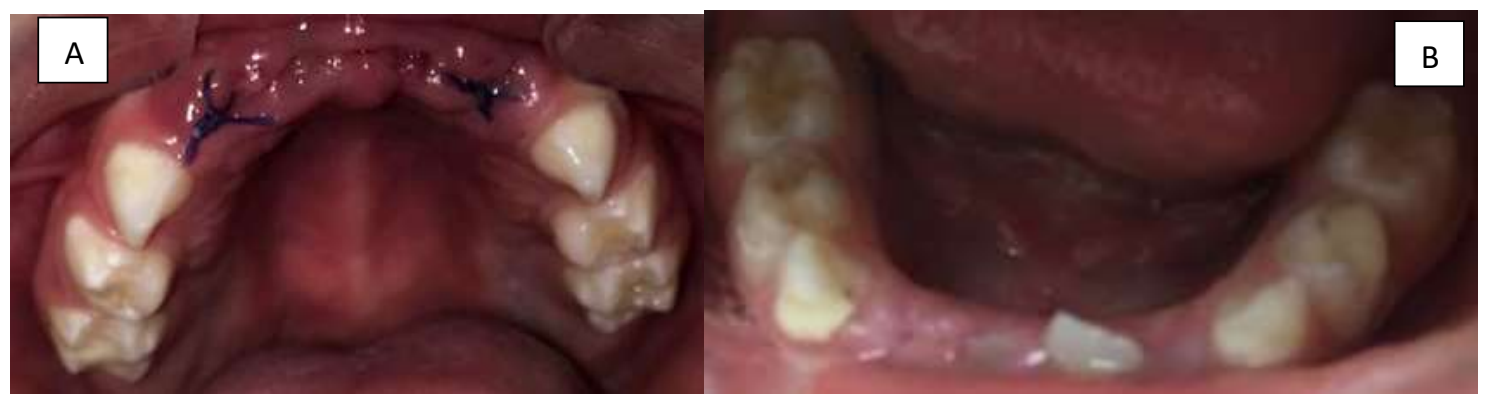

Source: Personal archive.

Chart 2 describes the dental procedures carried out at the Alzira Velano University Hospital, in Alfenas, Minas Gerais, Brazil. 
Chart 2. Dental procedures performed in the hospital day-care unit.

\begin{tabular}{|l|l|}
\hline Procedure & Tooth region (tooth number) \\
\hline Indirect pulp capping and restorations & $74,83,54$ \\
\hline Composite sealants & $75,84,85,55,64,65$ \\
\hline Extractions & $52,51,61,62,72,71,81,82$ \\
\hline Installation of aesthetic-functional space maintainer & Appliance in maxillary anterior teeth \\
\hline
\end{tabular}

Source: Personal archive.

Figure 5. Follow-up visit of the patient without and with the functional aesthetic device.

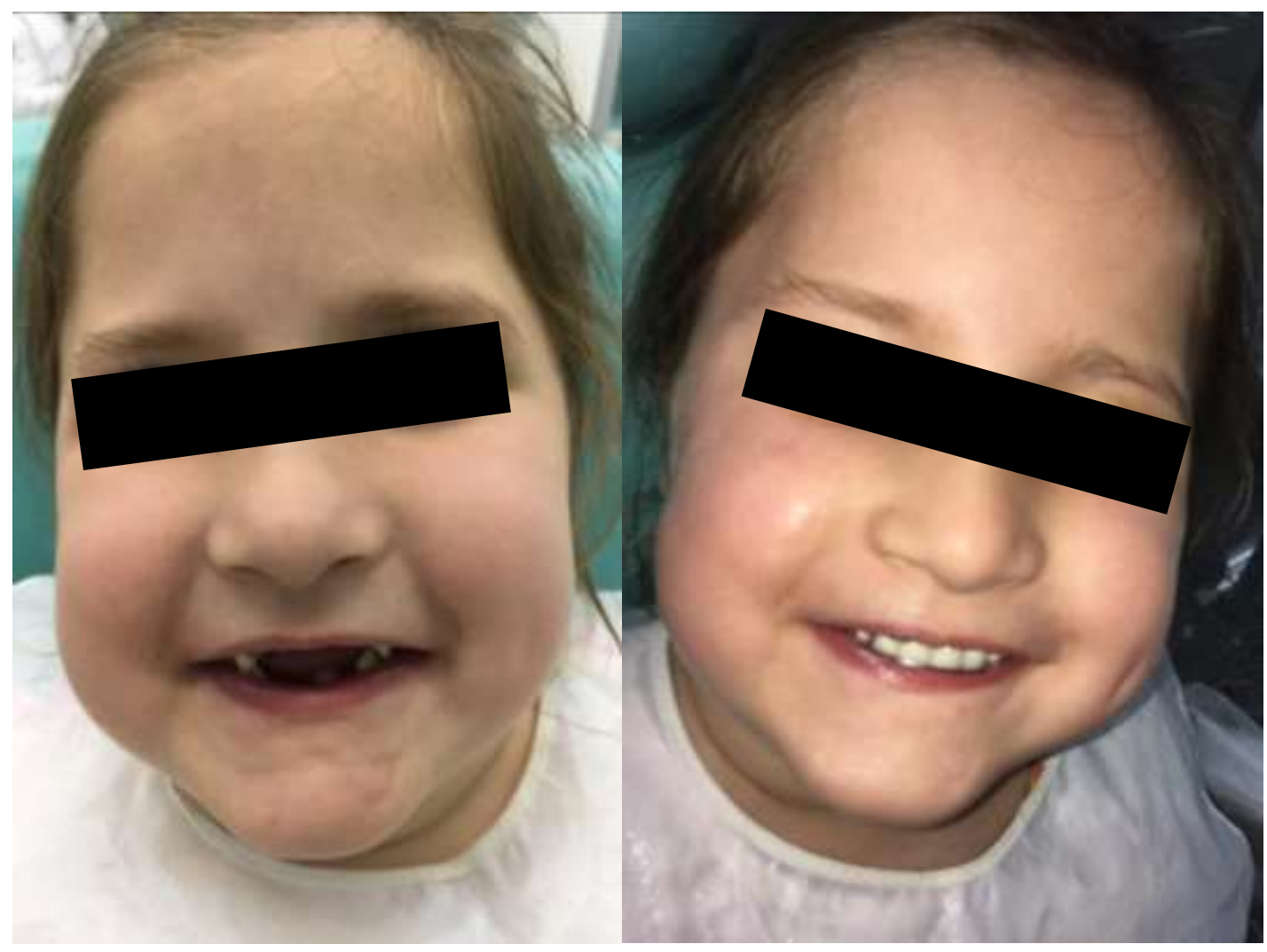

Source: Personal archive.

After 7 days, the patient and her mother returned to the dental clinic for follow-up visit. Then, the patient underwent finishing and polishing of dental restorations and repeated topical fluoride applications. Moreover, her mother received instructions on oral hygiene and diet, including supervised brushing practice. The mother was guided on how to clean and to use the maintenance appliance at home. She also received orientation about the need for replacement according to the child's development and to her upper teeth eruptions. The child presented a positive behavior during the follow-up visit.

\section{Discussion}

There is a lack of scientific literature regarding congenital heart disease in medical and dental fields. Since the discussion of stomatological management of this condition in pediatric patients remains scarce (Cornejo et al., 2011), this case report can improve dental care for children with severe systemic alterations. 
Children with congenital heart disease are commonly diagnosed just after birth and, in most cases, require cardiac surgery (Almeida et al., 1998). Importantly, the patient has a strict postoperative period and is hospitalized for a long period (Almeida et al., 1998; Behrman \& Kliggman 2005). In some cases, chronic administration of antibiotics is necessary and due to the large amount of sugar in the composition of these drugs, it becomes cariogenic (Peres et al., 2013). Thereby, the congenital cardiopathic patient may be predisposed to an increased incidence of caries.

In Brazil, most children of preschool age did not receive dental care in the primary health system (Peres et al., 2013), possibly owing to the lack of training for dentists in behavior management to assist these patient conditions. The care of these patients has serious limitations and must be faithfully considered and carried out with due precautions. Currently, different pharmacological techniques of behavioral management have been used according to the limitation of each patient, such as Bach flowers, sedation and general anesthesia (Bönecker et al., 2018). A previous review comparing sedation with general anesthesia revealed that dental procedures under general anesthesia are a therapeutic option for many children, as they can provide comprehensive and high-quality dental care (Abolfotouh et al., 2020). Dental procedures in children are performed under general anesthesia for numerous reasons, including prolonged surgical treatments and patients who need special safety conditions, such as congenital heart disease. In this case, several consultations and antibiotic prophylaxis would be required in all sessions aiming to reduce the effects of antibiotic prophylaxis. Thus, a safe alternative was to perform all procedures in a single session (American Academy on Pediatric Dentistry Council on Clinical Affairs., 2008; Abolfotouh et al., 2020).

In the present case report, we followed the Guidelines of the American Heart Association, which recommends antibiotic prophylaxis before invasive dental procedures to prevent the occurrence of bacteria and IE (Nishimura et al., 2008). Therefore, due to the patient's systemic condition and the need for continuity of procedures, whether surgical, periodontal or endodontic, they must be performed under antibiotic coverage (Nishimura et al., 2008). Oral health care and control of dental biofilm should be the first steps in the prevention of IE of odontogenic origin (Cavezzi., 2010). So, the procedures were planned and performed on the day of hospital visit.

Regarding future perspectives, this case will provide guidance on dental care of patients with congenital heart disease, whether they are invasive or non-invasive procedures. The prevention of oral diseases in patients with this systemic condition should be considered, including oral hygiene instruction with supervised brushing, fluoride topical application and also guidelines on diet to avoid caries and other oral diseases, which may lead to the need for invasive procedures.

Thus, multidisciplinary communication between the Cardiologist, Pediatrician and Pediatric Dentist on the characteristics of patients with systemic conditions and dental treatment needs is fundamental to promote prevention and avoid procedures that require the use of antibiotic prophylaxis (Cavezzi., 2010). In cases of patients with congenital heart disease, prevention is the most important aspect to avoid severe conditions. For this reason, an earlier approach is required through the indication of a correct diet, oral hygiene instruction and professional prophylaxis with a pediatric dentist.

\section{Final Considerations}

The dental treatment under general anesthesia was safe and comfortable for the child, since it was possible to perform all dental procedures without any suffering. Furthermore, the family was satisfied to find a dental team who solved the child's dental pain and also allowed her to be introduced to the dental setting. The adherence to the follow-up was essential to keep the pediatric dental care and also to manage the child's behavior during a dental visit.

\section{References}

Abolfotouh, M. A., Alhumaidan, G. A., Almalki, B. Y., Alhasson, A. H., Bushnak, I., \& Adlan, A. (2020). Predictors of dental general anesthesia receipt among children attending a tertiary hospital in Saudi Arabia. Ibnosina Journal of Medicine and Biomedical Sciences, 12 (4), 288. 
Research, Society and Development, v. 10, n. 6, e56510615907, 2021

(CC BY 4.0) | ISSN 2525-3409 | DOI: http://dx.doi.org/10.33448/rsd-v10i6.15907

Adatia, I., \& Gittenberger-de Groot, A. C. (1995). Unroofed coronary sinus and coronary sinus orifice atresia: implications for management of complex congenital heart disease. Journal of the American College of Cardiology, 25(4), 948-953.

Aidasani, B., Solanki, M., \& Khetarpal, S. (2019). Antibiotics: their use and misuse in paediatric dentistry. A systematic review. European journal of paediatric dentistry, 20(2), 133-138.

Almeida, F. A., Pedra, C. A. C., Jesus, C. A. D., Pedra, S. R. F. F., Fontes, V. F., \& Sousa, L. C. B. D. (1998). Comunicação interatrial do tipo seio coronário, comunicação interventricular e ausência de veia cava superior esquerda. Arquivos brasileiros de cardiologia, 71(4), 613-617.

American Academy of Pediatric Dentistry (2020). Use of antibiotic therapy for pediatric dental patients. The Reference Manual of Pediatric Dentistry. Chicago, Ill.: American Academy of Pediatric Dentistry;:443-6.

American Academy on Pediatric Dentistry Council on Clinical Affairs. (2008). Policy on the use of deep sedation and general anesthesia in the pediatric dental office. Pediatric dentistry, 30 (7 Suppl), 66-67.

Behrman, R. E., \& Kliegman, R. M. (2004). Nelson princípios de pediatria. In Nelson princípios de pediatria (pp. 690-690).

Behrman, R. E., \& Kliegman, R. M. (2005). Nelson princípios de pediatria. In Nelson princípios de pediatria.

Bönecker M., Abanto J., Imparato J.C.P., Corrêa M.S.N.P., Guedes-Pinto A.C. (2018) Odontopediatria: evidências científicas para a conduta clínica em bebês e pré-escolares. Quintessence.

Cavezzi Junior, O. (2010). Endocardite infecciosa e profilaxia antibiótica: um assunto que permanece controverso para a odontologia. RSBO (Online), 7(3), $372-376$.

Cornejo, K. B. Z., Brener, I. V., \& Bouchan, D. R. (2011). Manejo estomatológico del paciente pediátrico con cardiopatía congénita. Revisión de la literatura. Universitas Odontológica, 30(64), 57-66.

Coté, C. J., Wilson, S., American Academy of Pediatrics, \& American Academy of Pediatric Dentistry. (2006). Guidelines for monitoring and management of pediatric patients during and after sedation for diagnostic and therapeutic procedures: an update. Pediatrics, 118(6), 2587-2602.

Frankl, S. N. (1962). Should the parent remain with the child in the dental operatory? J. Dent. Child, 29, 150-163.

Glenny, A. M., Oliver, R., Roberts, G. J., Hooper, L., \& Worthington, H. V. (2013). Antibiotics for the prophylaxis of bacterial endocarditis in dentistry. Cochrane Database of Systematic Reviews, (10).

Kelly, R., Kidy, S., Allen, P., \& Sittampalam, G. (2018). Paediatric dentistry: Child caries and antibiotics. British dental journal, $225(12), 1048-1049$.

Nishimura, R. A., Carabello, B. A., Faxon, D. P., Freed, M. D., Lytle, B. W., O'Gara, P. T., \& Shah, P. M. (2008). ACC/AHA 2008 Guideline update on valvular heart disease: focused update on infective endocarditis: a report of the American College of Cardiology/American Heart Association Task Force on Practice Guidelines endorsed by the Society of Cardiovascular Anesthesiologists, Society for Cardiovascular Angiography and Interventions, and Society of Thoracic Surgeons. Journal of the American College of Cardiology, 52(8), 676-685.

Peres, M. A., Barbato, P. R., Reis, S. C. G. B., Freitas, C. H. S. D. M., \& Antunes, J. L. F. (2013). Perdas dentárias no Brasil: análise da Pesquisa Nacional de Saúde Bucal 2010. Revista de saude publica, 47, 78-89.

Sun, R., Liu, M., Lu, L., Zheng, Y., \& Zhang, P. (2015). Congenital heart disease: causes, diagnosis, symptoms, and treatments. Cell biochemistry and biophysics, 72(3), 857-860.

Vaughan, V. C., McKay, R. J., \& Behrman, R. E. (1983). Nelson: tratado de pediatria. In Nelson: tratado de pediatria (pp. 2028-2028). 